\title{
Rhizobium phaseoli tolerant to insecticide on the growth of Phaseolus vulgaris
}

\section{Rhizobium phaseoli tolerante a un insecticida en el crecimiento de Phaseolus vulgaris}

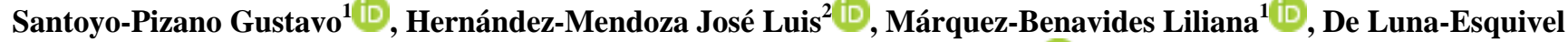 \\ Gustavo $^{3}$ Sánchez-Yáñez Juan Manuel ${ }^{1 *(D)}$
}

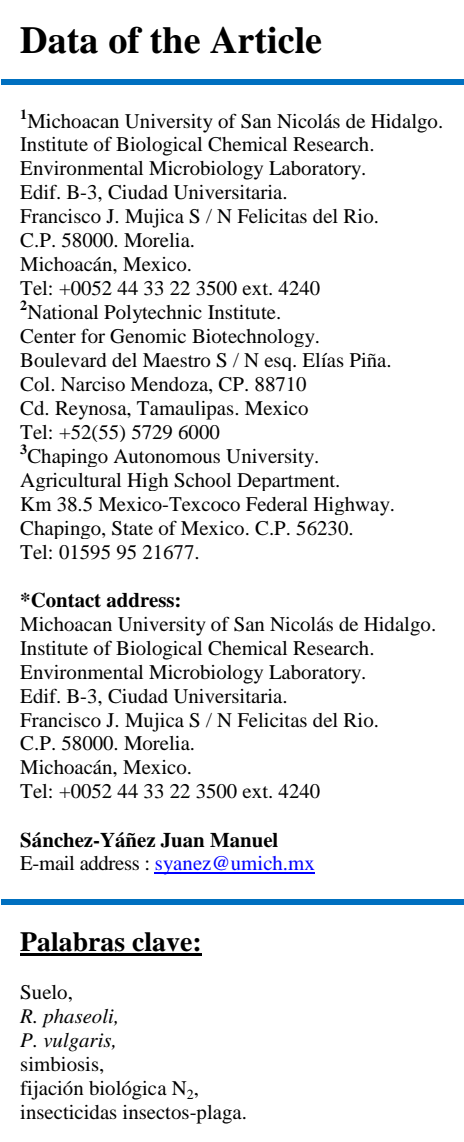

\section{J. Selva Andina Res. Soc.} 2021; 12(1):30-37. ID of article 146/JSARS/2020

\section{Record from the article}

Received July 2020.

Returned november 2020

Accepted December 2020

Available online, February 2021

\begin{tabular}{|c|}
\hline $\begin{array}{c}\text { Edited by: } \\
\text { Selva Andina } \\
\text { Research Society }\end{array}$ \\
\hline Keywords: \\
\hline $\begin{array}{l}\text { Soil, } \\
\text { R. phaseoli, } \\
\text { P. vulgaris, } \\
\text { symbiosis, } \\
\text { biological } \mathrm{N}_{2} \text { fixing, } \\
\text { insecticides, insect-pest. }\end{array}$ \\
\hline
\end{tabular}

\section{Resumen}

El género y especie Rhizobium phaseoli es usado como inoculante en la producción de Phaseolus vulgaris (fríjol), porque en los nódulos de sus raíces, establece una simbiosis para fijar el nitrógeno molecular (FBN) y suplir la demanda de nitrógeno (N) para un crecimiento sano. En el cultivo de $P$. vulgaris se aplican plaguicidas en el control de insectos plaga de raíz, que evitan el efecto benéfico de $R$. phaseoli., por lo que los objetivos de este trabajo fueron aislar y seleccionar $R$. phaseoli tolerante a diazinón. Para ello, $R$. phaseoli se creció en caldo extracto levadura manitol con diazinón y selecciono $R$. phaseoli tolerante al insecticida e inoculó en $P$. vulgaris para determinar la infectividad con base en el número de nódulos, mientras que la efectividad para la FBN en la raíz, de acuerdo al incremento en el peso fresco y seco, en la altura de la planta, y en la capacidad para degradar el diazinón. Se concluye que el $R$. phaseoli tolerante a diazinón fue infectivo y efectivo para el sano crecimiento de P. vulgaris.

2021. Journal of the Selva Andina Research Society®. Bolivia. Todos los derechos reservados.

\section{Abstract}

The genus and species of Rhizobium phaseoli are useful as an inoculant for the production of Phaseolus vulgaris (beans) in the root nodules symbiotic stage fixes molecular nitrogen $(\mathrm{FN})$ for supplying nitrogen $(\mathrm{N})$ for healthy growth. In P. vulgaris cropping, pesticides are used to control root insects, which could reduce the beneficial effect of R. phaseoli. The purpose of this work was to isolate and select R. phaseoli diazinon's tolerance. In that sense, R. phaseoli were cultivated in a medium mixed with diazinon in order to select R. phaseoli tolerant to the pesticide. This mutant of R. phaseoli tolerant to diazinon was inoculated in P. vulgaris the effect was evaluated 45 days later. The response of P. vulgaris was measured by the number of effective nodules at the roots, fresh and dry weight, and the height of the plant. Results showed that R. phaseoli tolerant to diazinon kept its beneficial activity for the healthy growth of P. vulgaris. It was concluded that R. phaseoli tolerant to diazinon were infective and effective for the health growth of P. vulgaris. 


\section{Introduction}

The symbiosis between legumes and Rhizobium is essential in agriculture due to the positive impact it has on the cultivation and consumption of Phaseolus vulgaris and other legumes ${ }^{1}$. Inoculating P. vulgaris seed with Rhizobium phaseoli avoids nitrogen hyperfertilization to the soil, in addition to ensuring the healthy growth and profitable yield of P. vulgaris $^{1}$ whose grain is considered one of the main in Mexico, in principle due to its high consumption and production, hence the economic importance ${ }^{2}$.

One of the problems to ensure a healthy growth of $P$. vulgaris, is the control of insects-pests that damage the root, thus avoiding the beneficial action of $R$. phaseoli $i^{3}$, first to exert the infectivity or formation of nodules and the effectiveness or the ability of $R$. phaseoli to adequately supply the nitrogen (N) demand for healthy growth. Consequently, pesticides are applied that generally inhibit or kill $R$. phaseoli, however, the information in this regard is contradictory, since it is reported that the growth of $R$. phaseoli is inhibited with minimal concentrations of dichloro diphenyl trichloroethane (DDT) and folidol, being lower than those recommended in the field in the pest control of roots of $P$. vulgaris. While other research reported that Rhizobium spp., can be tolerant to pesticides without losing the infective and effective capacity $\frac{4,5}{5}$. Thus, it has been reported that nodulation in the root system of $P$. vulgaris by $R$. phaseoli is inhibited or reduced due to the toxicity of these pesticides $\frac{6,7}{}$, which decreases the effectiveness or positive effect for the healthy growth of $P$. vulgaris, basically because they inactivate nitrogenase to fix molecular nitrogen $\left(\mathrm{N}_{2}\right)$ or $\mathrm{FN}_{2} \frac{8,9}{}$. In that sense the objectives of this research was the selection and analysis diazinon-tolerant $R$. phaseoli for the healthy growth of $P$. vulgaris.

\section{Materials and methods}

Origin of the $R$. phaseoli isolated. $R$. phaseoli were isolated from the roots of Phaseolus var Bayo, in congo red yeast extract mannitol agar (CRYEMA) with the following composition $(\mathrm{g} / \mathrm{L}): \mathrm{K}_{2} \mathrm{HPO}_{4}$ 0.5, $\mathrm{MgSO}_{4} 0.2, \mathrm{NaCl} 0.1$, mannitol 1.0, yeast extract 1.0 , congo red $10.0 \mathrm{~mL} / \mathrm{L}$ (from a 1:500 solution), agar $20.0 \mathrm{~g}, 1000.0 \mathrm{~mL}$ distilled water, $\mathrm{pH} 7.0$ according to Vincent $t^{\frac{10}{}}$, collected from the experimental agricultural field of the National Institute of Forestry, Agricultural and Livestock Research (INIFAP), Aldama, Tamaulipas, Mexico, were designated with the codes: ReD, ReDa and ReD1, they are part of the collection of the Environmental Microbiology laboratory of the Institute of Biological Chemical Research (IIQB) -Universidad Michoacana de San Nicolás de Hidalgo (UMSNH) $\frac{1,10}{\text {. }}$

Selection of $R$. phaseoli tolerant to diazinon. In this trial, pesticides frequently applied in Aldama Tamaulipas, Mexico, were tested, such as: diazinon (O, O-diethyl O-2-isopropyl-6-methylpyridin-4-yl phosphorothioate) - Servin (1-naphthyl N- methyl carbamate), c/pesticide was added to the CRYEMA in concentrations of: 250, 300, 500 and 100 ppm, in a nephelometric flask, $1.0 \mathrm{~mL}$ equivalent to $1 \times 10^{6}$ $\mathrm{CFU} / \mathrm{mL}$ of $R$. phaseoli was inoculated per $100 \mathrm{~mL}$ of yeast mannitol extract broth (YMEB) plus diazinon or Servin in concentrations of: 200, 300, 400 and $1000 \mathrm{ppm}$, these flasks were incubated for 24 to $36 \mathrm{~h}$ in shaking/200 rpm, for adaptation and selection of $R$. phaseoli to the increasing concentration of diazinon and Servin. The adaptation of $R$. phaseoli to the increase in the concentration of each pesticide 
was achieved by detecting the growth expected with that increase, compared to the normal growth of $R$. phaseoli in the nephelometric flask in YMEB without diazinon or Servin under the same conditions. incubation time, temperature and time ${ }^{4}$.

Test of infectivity and effectiveness of $R$. phaseoli resistant to diazinon in $P$. vulgaris. The diazinontolerant strains of $R$. phaseoli were selected (since Servin inhibited the growth of $R$. phaseoli from the first concentration so it was no longer used).

\section{Figure 1 Leonard' jar}

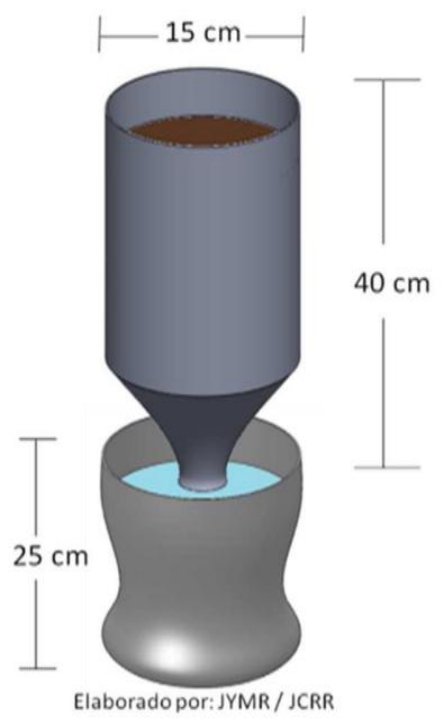

Therefore, the seeds of $P$. vulgaris var Bayo (donated by the Secretary of Agriculture, Livestock, Fisheries, Rural Development and Food of the Mexican government) were inoculated with $R$. phaseoli resistant to diazinon in Leonard's jars (figure 1) there the soil was placed in the upper part of Leonard's Jar and the mineral solution or water in the lower part of the Jar, both parts were connected with a 20 $\mathrm{cm}$ long cotton strip, for movement of the liquid by capillary action ${ }^{\frac{5}{}}$, The soil where $P$. vulgaris was sowing had the follo-wing physicochemical properties: it was a lateritic with $\mathrm{pH} 6.64$, clay texture $40.56 \%$, sand $0.76 \%$, silt $37.8 \%$, field capacity $30.08 \%$, organic matter humidity $4.57 \%$, poor in total nitrogen $0.1 \%$, field capacity $30.08 \%$, and cation exchange capacity of $4.61 \mathrm{mg} / 100 \mathrm{~g}$. This soil was sieved with a mesh of No. 20 , it was solarized $48 \mathrm{~h}$ at $70{ }^{\circ} \mathrm{C}$, to avoid pests and diseases, Leonard's Jars were placed in the greenhouse under the following average micro-climatic conditions were: the temperature of $23.2{ }^{\circ} \mathrm{C}$, with a brightness of $450 \mu \mathrm{mol} \cdot \mathrm{m}^{-2} \cdot \mathrm{s}^{-1}$ and a relative humidity of $67 \%$. $P$. vulgare with $R$. phaseoli was fed with a mineral solution with the following chemical composition: 1 molar of $\mathrm{K}_{2} \mathrm{HPO}_{4}, \mathrm{KH}_{2} \mathrm{PO}_{4}, \mathrm{CaCl}_{2}, \mathrm{MgSO}_{4}$, traces of $\mathrm{FeSO}_{4}, 1.0 \mathrm{~mL}$ of minor elements solution in $1000 \mathrm{~mL}$ of distilled water adjusted to $\mathrm{pH} 7$ which was pasteurized $\left(90{ }^{\circ} \mathrm{C} / 10 \mathrm{~min}\right)$. Later 45 days later, the effect of diazinon-tolerant $R$. phaseoli strains in $P$. vulgaris was evaluated by means of the following response variables, plant height $(\mathrm{PH})$, leaf diameter (LD) $(\mathrm{cm})$, as well as the dry weight of the foliage (DWF), number of effective nodules in the root its dry weight and the dry weight of the $\operatorname{root}^{\frac{10}{10}}$. Evidence that $R$. phaseoli degraded (coometabolism) diazinon in culture medium.

The diazinon-tolerant $R$. phaseoli strains were inoculated in a nephelometric flask, with congo red mannitol yeast extract broth (CRMYEB) with diazinon, the flasks were shaken at $300 \mathrm{rpm}$ until the stationary phase, by means of a viable count that was reached at $30 \mathrm{~h}$ of incubation according to the growth curve of $R$. phaseoli, in comparison with the same $R$. pha-seoli in CRMYEB without diazinon. This test sho-wed the coometabolism of $R$. phaseoli 
to degrade diazinon in combination with mannitol used as a carbon source $\mathrm{A}^{4,11-13}$.

\section{Results}

Table 1 Effect of diazinon-tolerant Rhizobium phaseoli on the growth of Phaseolus vulgaris var Bayo

\begin{tabular}{lccc}
\hline \multicolumn{1}{c}{ Strain } & ReD & ReDa & ReD1 \\
\hline $\begin{array}{l}\text { No. of effective nodules }(\text { red })^{1} \\
\text { Leaves color }\end{array}$ & $19^{c^{*}}$ & $20^{c}$ & $39^{\mathrm{a}}$ \\
${ }_{\mathrm{n}=20 * \text { equal letters without statistical differences according to Tukey }(\mathrm{p}<0.05)}$ & \multicolumn{2}{c}{ Green } & Intense green \\
\hline
\end{tabular}

Table 1 shows the effect of diazinon-tolerant $R$. phaseoli strains on the growth of $P$. vulgaris as a function of the number of effective nodules that determine a plant health condition with 19, 20, 39 generated respectively by the strains of $R$. phaseoli resistant to diazinon called $\mathrm{ReD}, \mathrm{ReDa}$ and $\mathrm{ReD} 1$.
Regarding the color of $P$. vulgaris leaves, they were indicative that the isolated infected the roots of $P$. vulgaris formed red nodules (effective), which indicates the presence of leghemoglobin associated with its capacity to fix $\mathrm{N}_{2}$ and the color intense green on the leaves ${ }^{1}$.

Table 2 Comparison of the infectivity and effectiveness of wild Rhizobium phaseoli and diazinon-tolerant Rhizobium phaseoli on the growth of Phaseolus vulgaris var Bayo

\begin{tabular}{|c|c|c|c|c|c|c|}
\hline \multirow{2}{*}{$\begin{array}{l}{ }^{1} \text { Infectivity stability and } \\
\text { effectiveness parameters }\end{array}$} & \multicolumn{3}{|c|}{ R.phaseoli silvestre } & \multicolumn{3}{|c|}{ R. phaseoli tolerante a diazinón } \\
\hline & ReD & ReD1 & ReDa & ReD & ReD1 & ReDa \\
\hline Leaf diameter $(\mathrm{cm})$ & $3.7^{\mathrm{a} *}$ & $3.9^{\mathrm{a}}$ & $3.5^{\mathrm{a}}$ & $3.2^{\mathrm{a}}$ & $3.6^{\mathrm{a}}$ & $3.1^{\mathrm{a}}$ \\
\hline Plant height $(\mathrm{cm})$ & $23^{\mathrm{b}}$ & $29^{\mathrm{a}}$ & $22^{\mathrm{b}}$ & $19.1^{\mathrm{c}}$ & $24.9^{\mathrm{b}}$ & $18.0^{\mathrm{c}}$ \\
\hline Foliage dry weight $(\mathrm{g})$ & $5.0^{\mathrm{a}}$ & $3.9^{\mathrm{b}}$ & $4.0^{\mathrm{b}}$ & $4.9^{\mathrm{a}}$ & $3.6^{\mathrm{b}}$ & $3.9^{\mathrm{b}}$ \\
\hline Dry weight of effective nodules (mg) & $490^{\mathrm{b}}$ & $498^{\mathrm{a}}$ & $130^{\mathrm{c}}$ & $488^{\mathrm{b}}$ & $509^{\mathrm{a}}$ & $100^{\mathrm{c}}$ \\
\hline Number of effective nodules (red)/plant & $25^{\mathrm{b}}$ & $29^{\mathrm{a}}$ & $22^{\mathrm{b}}$ & $21.0^{\mathrm{b}}$ & $27.0^{\mathrm{a}}$ & $19.0^{\mathrm{b}}$ \\
\hline Root dry weight with nodules (g) & $3.2^{\mathrm{a}}$ & $3.8^{\mathrm{b}}$ & $4.9^{\mathrm{a}}$ & $4.0^{\mathrm{b}}$ & $3.5^{\mathrm{b}}$ & $4.2^{\mathrm{a}}$ \\
\hline
\end{tabular}

In table 2, where according to the literature it was observed that the diazinon-tolerant $R$. phaseoli coding as $\mathrm{ReD}, \mathrm{ReDa}$ and $\mathrm{ReD} 1$ had a positive effect on the LD, and PH of P. vulgaris with 19.1, 24.9, 18 $\mathrm{cm}$, as well as in the DWF, these numerical values were statistically different in comparison with the wild $R$. phaseoli isolates unable to grow in the presence of diazinon. Like the diazinon-tolerant $R$. phaseoli isolates in the number of effective red nodules, the dry weight that included that of the complete root, not statistical difference compared to the analogous numerical values registered in $P$. vulgaris with wild $R$. phaseoli non-diazinon tolerant.

Table 3 shows that $R$. phaseoli strains grown in CRYEMA with diazinon generated a number of 33 colony forming units (CFU) with a statistically different numerical value compared to wild $R$. phaseoli isolated (wild) in CRYEMA without diazinon, which indicates that the isolates subjected to the maximum concentration of diazinon were physiologically adap-ted to the insecticide, although there was a reduction in the UFC $R$. phaseoli, since it is a natural selection which caused the death of the cells of $R$. phaseoli that are susceptible to diazinon toxicity ${ }^{4}$.

Table 4 shows the growth as CFU, registered in diazinon-tolerant $R$. phaseoli isolates, the literature indicates that it may be due to an action of coometabolism when they use mannitol for the degradation of diazinon, in this table it was evident that 
when $R$. phaseoli grew in mannitol and diazinon, a decrease in the number of colonies was registered as CFU, because although $R$. phaseoli degraded it, it was toxic for a part of the total population of $R$. phaseoli, compared to when it grew in the CRYEMA without diazinon, which represents the amount of the expected CFU growth, while by suppressing mannitol and diazinon, the absence of both caused a drastic decrease in the $R$. phaseoli population, because the other components of CRYEMA: like yeast extract and Congo red were insufficient for $R$. phaseoli to reproduce at the level registered when the culture medium contained mannitol as sole source of carbon and energy ${ }^{1}$.

\section{Table 3 Comparison of the stability of resistence of Rhizobium phaseoli to diazinon compared to wild} Rhizobium phaseoli

\begin{tabular}{ccc}
\hline Isolated & ${ }^{*}$ CRYEMA with diazinon ${ }^{1}$ CFUx10 & CRYEMA without diazinon $^{1}$ CFUx10 \\
\hline $\operatorname{ReD}$ & $26^{\mathrm{c} * *}$ & $44^{\mathrm{b}}$ \\
$\operatorname{ReD} 1$ & $30^{\mathrm{c}}$ & $49^{\mathrm{b}}$ \\
$\operatorname{ReDa}$ & $40^{\mathrm{b}}$ & $61^{\mathrm{a}}$ \\
\hline average of 4 repetitions in CFU = Colony Forming Units $\times 10^{2} / \mathrm{mL}^{*} \mathrm{CRYEMA}=$ congo red yeast extract mannitol agar. \\
"Equal letters without statistical differences according to Tukey $(\mathrm{p}<0.05)$.
\end{tabular}

Table 4 Diazinon coometabolism by insecticide tolerant Rhizobium phaseoli isolates comparad to the growth without insecticideon the wild Rhizobium phaseoli

\begin{tabular}{cccc}
\hline Strain & $\begin{array}{c}{ }^{2} \text { Congo red yeast extract } \\
\text { mannitol agar without } \\
\text { diazinon }{ }^{1} \text { CFUx10 }\end{array}$ & $\begin{array}{c}\text { Congo red yeast extract } \\
\text { mannitol agar with } \\
\text { diazinon }^{1} \text { CFUx10 }\end{array}$ & $\begin{array}{c}\text { Congo red yeast extract } \\
\text { agar without mannitol } \\
\text { or diazinon }^{1} \text { CFUx10 }^{2}\end{array}$ \\
\cline { 2 - 4 } $\operatorname{ReD}$ & $39^{\mathrm{c} *}$ & $15 .^{\mathrm{d}}$ & $0.1^{\mathrm{e}}$ \\
$\mathrm{ReD} 1$ & $50^{\mathrm{b}}$ & $23^{\mathrm{c}}$ & $0.9^{\mathrm{e}}$ \\
$\mathrm{ReDa}$ & $60^{\mathrm{a}}$ & $31^{\mathrm{c}}$ & $0.7^{\mathrm{e}}$ \\
\hline
\end{tabular}

${ }^{\mathrm{T}} \mathrm{CFU}=$ Colony Forming Units $/ \mathrm{mL} ;{ }^{*}$ Equal letters without statistical differences according to Tukey $(\mathrm{p}<0.05)$.

\section{Discussion}

Table 1 shows that a positive response of $P$. vulgaris was observed based on the number of effective nodu-les, which supports that diazinon-tolerant $R$. phaseoli conserved plasmids that contain infectivity and effectiveness in the roots of $P$. vulgaris, for healthy growth, because there was insufficient mineral nitrogen in the soil for the growth of P. vulgar$i s^{1,5,6,12}$.

Table 2 shows that the diazinon-tolerant $R$. phaseoli strains conserved the plasmids responsible for nodulation or infectivity, which were red in color, indicating the presence of leghemoglobin, a protein related to the ability to fix $\mathrm{N}_{2}$ (effectiveness ), consequently $P$. vulgaris synthesized enough chloro- phyll, for the intense green color of the leaves, a phenological characteristic of a healthy growth when $P$. vulgaris is symbiosis with strains of $R$. phaseoli that are infective and effective $7, \underline{70}, \underline{13}$.

Table 3 shows the evidence that the growth of $R$. phaseoli in yeast mannitol extract agar (YMEA) with diazinon based on CFU, was the result of a natural selection of the physiological adaptation to diazinon, without the risk of losing the capability to grow in the presence of diazinon, the numerical value of the CFU, was reduced in relation to the same variable of CFU, of the wild strains of $R$. phaseoli, because during the selection a part of this population susceptible to diazinon died, therefore, the number of CFU of $R$. phaseoli tolerant to diazinon was lower $\frac{14-16}{}$. As has been reported for other genera, species of the Rhizobiaceae family such as 
Bradyrhizobium spp., which also co-metabolize and/or mineralize other applied pesticides, in conventional agriculture in the control of insects-pests

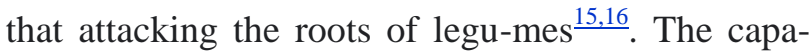
bility to degrade insecticides similar to diazinon, is a common biochemical property in nature according to those reported for other bacterial groups other than $R$. phaseoli such as: Pseudomonas, as well as actinomycetes: Streptomyces, Micromonospora, Thermoactinomyces, Nocardia and Mycobacterium $^{4,12,13}$ and other genera and species of soil fungi, and/or those endophytic living in association with plant roots of the type: Aspergillus fumigatus, Cunninghamella elegans ${ }^{17}$, Penicillium citreoni-grum ${ }^{18}$. Rhizopus nodosus, includes the human pathogenic enterobacteria: Escherichia coli, Salmonella bongo$r i$ that are capable of mineralizing diazinon, the above supports this is because both eukaryotes and prokaryotes have this genetic property of resistance to diazinon, because they are related to human activities of plant and water management that are part of agriculture $\frac{19-21}{}$.

Table 4 shows the tolerance of $R$. phaseoli to diazinon was the results of the physiological adaptation capacity of this genus and species, which also has the codified genome using as only source carbon some compounds similar to diazinon, so if there is another simple carbon source that, when is oxidized, made easy the degradation of the pesticide, a biochemical action known as coometabolism. What was showed that when $R$. phaseoli tolerant to diazinon grew in CRYEMA and diazinon, compared to the inhibition of growth of $R$. phaseoli in CRYEMA without mannitol or diazinon ${ }^{4,8,81}, \underline{14}$. The selection of strains of $R$. phaseoli tolerant to pesticides is useful in conventional agriculture, its has been reported on Bradyrhizobium japonicum strains for producing Glycine max to avoid attacking of pest insects $\underline{15,22,23}$. For this reason $R$. phaseoli is recommended in agricultural issues where $P$. vulgaris has a problem with insect pest destroying roots and limiting its healthy growth, underline due diazinon is applied for producing $P$. vulgaris in doses similar to those evaluated in this research $\frac{12}{}$, since diazinon is applied at the begining growth steps of $P$. vulgaris without evidence that its persistence in $P$. vulgaris tissues and/or seeds ${ }^{14}$. Based on the above, its concluded that it is possible to isolate diazinon-tolerant strains of $R$. phaseoli that are highly infective and effective for a healthy growth of $P$. vulgaris without risk of lost caused by pest insects destroying its root system.

\section{Funding source and Acknowledgments}

To Project 2.7 (2021) of the CIC-UMSNH, BIONUTRA SA de CV of Maravatío, Michoacán, Mexico, to Jeanneth Caicedo Rengifo in writing, to: EDI, COFAA- IPN and SNI for the support.

\section{Conflicts of interest}

The authors of this article declare that there is no conflict of interest in the planning, execution and writing of the research carried out, nor with those people and institutions that financed it.

\section{Ethical considerations}

The approval of the research by the Ethics Committee of the Universidad Michoacana de San Nicolás de Hidalgo, Mexico followed the guidelines established by that committee.

\section{Authors' contribution to the article}

Santoyo Pizano Gustavo, planning of the experiment and statistical analysis of all results. Hernán- 
dez Mendoza José Luis, update of the literature and partial review of the literature for the experimental results. Marquez-Benavides Liliana, analysis of results and criticism of the discussion of results. De Luna-Esquivel Gustavo, support for the experimental design and execution of experiments with Phaseolus vulgaris and Rhizobium phaseoli. Sánchez-Yáñez Juan Manuel, Planning, direction of the experiments, comprehensive analysis of results, writing of the article, responsible for the financial support of the research.

\section{Cited Literature}

1. Villegas MJ, Farias Rodriguez R, Sánchez Yáñez JM. Inoculación de leguminosas con Rhizobium: mini revisión [Internet]. Morelia: Universidad Michoacana de San Nicolás de Hidalgo; 2005 [citado 22 de mayo de 2020]. 12 p. Recuperado a partir de: file:///C:/Users/usuario/Downloads/Ino culaciondeleguminosasconRhizobium2005Topi cosSelectosMicrobiologia\%20(1).pdf

2. Programa especial concurrente para el desarrollo rural sustentable (PEC) para el ejercicio 2020 [Internet]. Centro de Estudios para el Desarrollo Rural Sustentable y la Soberanía Alimentaria. 2020 [citado 5 de agosto de 2020]. Recuperado a partir de: http://www.cedrssa.gob.mx/post programa especial concurrente para el desa rrollo rural sustentable_-n-pec-_para_el_ejer cicio_2020n.htm

3. Hussain S, Siddique T, Saleem M, Arshad M, Khalid A. Impact of pesticides on soil microbial diversity, enzymes, and biochemical reactions. Adv Agron 2009;102:159-200. DOI: https://doi. org/10.1016/S0065-2113(09)01005-0

4. Singh G, Wright D. In vitro studies on the effects of herbicides on the growth of rhizobia. Lett Appl
Microbiol 2002;35(1):12-6. DOI: https://doi.org/ 10.1046/j.1472-765x.2002.01117.x

5. Romero García VE, García Ortiz VR, Hernández Escareño JJ, Sánchez Yáñez JM. Respuesta de Phaseolus vulgaris a microorganismos promotores de crecimiento vegetal. Scientia Agropecuaria 2016;7(3):313-9. DOI: https://doi.org/10. 17268/sci.agropecu.2016.03.20

6. Alexander M. Biochemical ecology of microorganisms. Annu Rev Microbiol 1971;25:361-92. DOI: https://doi.org/10.1146/annurev.mi.25.1001 71.002045

7. Alexander M. Introducción a la microbiología del suelo. Mexico: AGT Editores; 1977. p. 463-481.

8. Somerville L. Perspectives on side-effect testing. In: Somerville L, Greaves MP, editors. Pesticide effects on soil microflora. London: Taylor and Francis; 1987. p. 240.

9. Ingram CW, Coyne MS, Williams DW. Effects of commercial diazinon and imidacloprid on microbial urease activity in soil and sod. J Environ Qual 2005;34(5):1573-80. DOI: https://doi.org/10. 2134/jeq2004.0433

10.Vincent JM. Manual práctico de rhizobiología. Buenos Aires: Hemisferio Sur; 1975. p. 10-50.

11.Lal R, Saxena DM., Accumulation metabolism and effects of organochlorine insecticides on microorganisms. Microbiol Rev 1982;46(1):95-127. DOI: https://doi.org/10.1128/MMBR.46.1.95-127 .1982

12.Das AC, Mukherjee D. Soil application of insecticides influences microorganisms and plant nutrients. Appl Soil Ecol 2000;14(1):55-62. DOI: https://doi.org/10.1016/S0929-1393(99)00042-6

13. Kantachote D, Naidu R, Singleton I, McClure N, Harch BD. Resistance of microbial populations in DDT-contaminated and uncontaminated soils. Appl Soil Ecol 2001;16(1):85-90. DOI: https:// doi.org/10.1016/S0929-1393(00)00058-5 
14.Smith MD, Hartnett DC, Rice CW. Effects of long-term fungicide applications on microbial properties in tallgrass prairie soil. Soil Biol Biochem 2000;32(7):935-46. DOI: https://doi.org/ 10.1016/S0038-0717(99)00223-0

15.Santos JB, Ferreira EA, Kasuya MCM, Silva AA, Procópio SO. Tolerance of Bradyrhizobium strains to glyphosate formulations. Crop Prot 2005;24(6):543-7. DOI: https://doi.org/10.1016/j. cropro.2004.10.007

16.Drufovka K, Danevčič T, Trebše P, Stopar D. Microorganisms trigger chemical degradation of diazinon. Int Biodeterior Biodegradation 2008;62 (3):293-6. DOI: https://doi.org/10.1016/j.ibiod .2008 .02 .003

17.Zhao M, Gu H, Zhang CJ, Jeong IH, Kim JH, Zhu YZ. Metabolism of insecticide diazinon by Cunninghamella elegans ATCC36112. RSC Adv 2020;10:19659. DOI: https://doi.org/10.1039/d0 $\underline{\mathrm{ra} 02253 \mathrm{e}}$

18.Jahin HS, Gaber SE, Hussain M. Bioremediation of diazinon pesticide from aqueous solution by fungal-strains isolated from wastewater. World $\mathbf{J}$ Chem 2020;15(1):15-23. DOI: https://doi.org/10. 5829/idosi.wjc.2020.15.23

19.Hassan MA, El Mubarak A, Assad YH. Effectiveness evaluation of bacterial species isolated from soil in bioremediation of diazinon, pirimicarb and atrazine pesticides. Int J Curr Microbiol App Sci 2020;9(3):914-21. DOI: https://doi.org/10.20546/ijcmas.2020.903.107

20.Eom IC, Rast C, Veber AM, Vasseur P. Ecotoxicity of a polycyclic aromatic hydrocarbon (PAH)-contaminated soil. Ecotoxicol Environ Saf 2007;67(2):190-205. DOI: https://doi.org/10. 1016/j.ecoenv.2006.12.020
21.Altieri M, Rosset PM. Prólogo. En: Pérez Consuegra N, editor. Manejo ecológico de plagas [Internet]. La Habana: Centro de Estudios de Desarrollo Agrario y Rural; 2004. p. 5-6. Recuperado a partir de: https://www.fcnym.unlp.edu.ar/cate dras/ecoplagas/Bibliografia.pdf

22.Braga R, Labrada R, Fornasari L, Fratini N. Manual para la capacitación de trabajadores de extensión y agricultores - alternativas al Bromuro de Metilo para la fumigación de los suelos [Internet]. Roma: Programa de las Naciones Unidas para el Medio Ambiente-Organización de las Naciones Unidas para la Agricultura y la Alimentación; 2003 [citado 22 de mayo de 2020]. 74-87 p. Recuperado a partir de: http://www.fao.org/3/Y1806S /Y1806S00.htm

23.Kaack H. Tomato es in Morocco: IPM and grafted plants. In: Batchelor T, editor. Case studies on alternatives to Methyl Bromide technologies with low environmental impact [Internet]. Paris: United Nations Environment Programme Division of Technology, Industry and Economics; 2000. p. 14-17. Recuperado a partir de: http://hdl.handle. net/20.500.11822/8331

Editor's Note:

Journal of the Selva Andina Research Society (JSARS) remains neutral with respect to jurisdictional claims published on maps and institutional affiliations. 